\title{
Basic Trends in the Evolving Law of the Sea and Their Implications for Ocean Use Management
}

Lawerence Juda University of Rhode Island - Kingston, Rhode Island USA

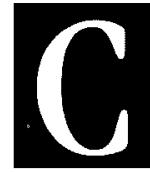

overing over seventy per cent of the earth's surface the world's oceans are a distinguishing feature of the planet. From a human use perspective, ocean areas are significant, providing food, energy, minerals, and a transportation highway that makes possible an integrated world economy. Accordingly, it is not surprising that considerable attention has been given to the international law of the sea since that body of law provides the legal framework for the management of the human utilization of ocean space and its resources.

The concept of freedom of the seas, as championed by the celebrated Dutch lawyer Hugo Grotius in his seminal work Mare Liberum in 1609, dominated legal thought into the twentieth century. Contemporary law as reflected in the 1982 United Nations Convention on the Law of the Sea, subsequent international agreements, and state practice embodies a different approach resulting from a variety of ocean use trends and developments. Clearly, as compared to law of this earlier period, present-day law indicates movement toward a more managed environment, with constraints and responsibilities being placed on states as they exercise their rights in ocean areas (Juda, 1996).

The primary forces now driving the transformation of the law of the sea are the increased human capability to exploit ocean resources due to technological advances and the greatly increasing demand for ocean resources resulting from the growth of world population. Over time human use of the ocean environment has been marked by a pattern of intensification of traditional uses, as in regard to fishing and maritime transportation, supplemented by the emergence of new uses, such as the exploitation of offshore oil and gas deposits. And new commercial uses of ocean areas, for example deep seabed mining for manganese nodules, may be on the horizon.

This observed pattern of human use has been accompanied by serious problems of overexploitation of living resources, damage to marine ecosystems, conflict of uses of ocean space, and disputes over the nature and extent of coastal state authority in offshore areas. At the same time, ocean science has advanced the understanding of natural ocean systems and the effects on those systems of human activities ranging from fishing to the introduction of pollutants into the marine environment.

In broad terms the development of ocean law in the twentieth century has been characterized by four interrelated major trends. The first is for greater national control and jurisdiction over those areas of ocean space subject to most intense human use.

The 1982 United Nations Law of the Sea Convention allows for notable widening of coastal state jurisdiction and control over more extensive ocean areas than had been the case under the legal regime codified by the first United Nations Conference on the Law of the Sea in 1958. This important development, reflected in state practice, has been termed "the ocean enclosure movement" (Ball, 1996; Alexander, 1983; Eckert, 1979). In 
particular, the growth of national control over ocean areas is manifested in several key developments:

\section{a. Recognition of a wider territorial sea}

The right to claim a territorial sea to a maximum of 12 nautical miles has been enshrined in the 1982 Law of the Sea Convention. Not surprisingly, most coastal states including the United States have asserted rights to the maximum extent, thus moving away from what often was seen as the traditional three mile limit of territorial seas, referred to as the "cannon-shot" rule. In the territorial sea the coastal state has full sovereignty, subject only to the right of innocent passage for foreign flag ships.

\section{b. Recognition of the exclusive economic zone (EEZ) in international law}

The legal right to establish EEZs extending to 200 miles from the baselines used to measure the territorial sea, sanctified in the 1982 United Nations Convention on the Law of the Sea, has been institutionalized by extensive state practice. This development, creating a new juridical zone between the territorial sea and the high seas, marks a major change in ocean law and provides the coastal state with management authority and responsibility over all the living or non-living resources found there. Since some 95 per cent of the world fish catch is taken within 200 miles of the coast and since that area is no longer treated as an international commons, accessible to fishermen of any and all states at will, the potential for effective management of the ocean's living resources has been increased.

In addition to control over natural resources in the EEZ, the coastal state has also acquired jurisdictional rights in regard to the establishment of artificial islands, installations, and structures, as well as in regard to marine pollution and scientific research. Of special concern to oceanographers is the fact that research within the EEZ must be conducted with the prior permission of the coastal state; scientific research now has become subject to the complications of a "consent regime" that imposes a number of obligations on researchers (Knauss, 1985a; Roach, 1996) and exemplifies the fact that the concept of "freedom of the seas" has been eroded.

c. Redefining the continental shelf to remove any doubt that the coastal state has sovereign rights over the resources of the entire continental margin, i.e., the continental shelf, slope, and rise, an area collectively referred to by legal writers (but not oceanographers) as the continental shelf

Where the physical continental margin is less than
200 miles, the legally defined continental shelf is recognized, nonetheless, to encompass the seafloor out to 200 miles from the baselines used to measure the territorial sea. Utilizing the "Irish formula," coastal state rights are also recognized in regard to legally defined continental shelf areas that extend beyond 200 miles (Prescott, 1985). The primary concern with the continental shelf relates to coastal state sovereign rights over mineral resources including oil and gas. But the legal regime of the continental shelf is of importance to the marine science community because scientific research in or on the legally defined continental shelf, as in the case of the EEZ, is subject to a consent regime controlled by the coastal state.

\section{d. Recognition of the right of archipelagic states to establish and utilize archipelag- ic baselines}

Under the 1982 United Nations Law of the Sea Convention, archipelagic states such as Indonesia and the Philippines are entitled to utilize straight archipelagic baselines connecting their outermost islands provided, among other things, that those baselines include the main islands and an area in which the ratio of the area of water to land is between 1:1 and 9:1. The practical effect of the use of such baselines is to enlarge substantially the ocean area falling within baselines as compared to a system of delimitation around each individual island component of an archipelagic state.

As a consequence of "ocean enclosure" approximately 37 per cent of the world's oceans come under some form of coastal state jurisdiction and control (Alexander, 1986). The significance of this figure is underscored by the reality that the ocean areas encompassed in territorial seas, EEZs, continental shelves, and archipelagic waters constitute the most heavily utilized areas of ocean space. All offshore oil, almost 30 per cent of the world's annual oil production, is taken from continental shelf areas. Further, as noted above, 95 per cent of world fish catch comes from within the 200 mile limit. It is necessary to observe, too, the importance of commercial and military navigation and overflight through or over territorial seas, straits used for international navigation, archipelagic waters, and other waters in which coastal states have some form of national jurisdiction. And finally, it is precisely these ocean areas where most waste products and pollutants are introduced into the world oceans.

Why has national jurisdiction of coastal states over ocean areas expanded as it has? Clearly, the day of the nation-state has not yet passed. The new states in Africa and Asia, together with the states of Latin America, were at the forefront of the movement to expand coastal state powers and prerogatives into ocean areas (Orrego 
Vicuña, 1984; Attard, 1987). In many respects such efforts are quite understandable, for without coastal state authority in areas off their shores, resources will be exploited by and for developed states rather than for the benefit of the adjacent coastal state. Concern with distant water fishing provided powerful impetus for the states of the developing world to champion the concept of the EEZ.

The second major trend in ocean law is the development of a legal system which increasingly recognizes the multiplicity of ocean uses and the need to provide a balanced regime that acknowledges the rights of coastal states but also those of the larger world community. While coastal state authority and jurisdiction in offshore areas obviously have expanded in the past half century, that expansion has been accomplished in the context of recognition of significant rights for noncoastal states. Whereas the earlier Grotian system of ocean law was formulated in an age in which the focus was on ocean navigation, the modern legal system has had to take into account growing concern with depletion of ocean resources and their allocation and conservation and with protection of the ocean environment, as well. The new law of the sea attempts to balance navigation rights, which are still of major significance, in terms of both economic and military matters, with the growing concern over ocean resource availability and over the state of the ocean environment.

The 1982 United Nations Law of the Sea Convention clearly conveys the fact that its framers conceived the oceans in three dimensional terms, subject to a variety of uses, some old and some new, through the entire vertical column of ocean space from sub-bottom through the water column and into the airspace above. In addition to the traditional uses of fishery exploitation and surface navigation, ocean space utilization was perceived to include waste disposal and transport, marine scientific research, military uses, submarine cables and pipelines, construction of artificial islands, structures, platforms, and installations, overflight, offshore port facilities, archaeological research, seabed mining, underwater navigation, exploitation of nonliving resources from the water column, and production of energy from water, currents, and winds. The Convention reflects an understanding that ocean space is used and will be used for a growing multiplicity of purposes.

Over time, greater sophistication and inventive genius have been displayed in developing new offshore juridical zones and acceptable legal formulations that acknowledge the complicated balance of interests and uses to which ocean space is subject. New forms of intermediate legal authority allowing for less than total coastal state control have been applied to ocean areas in proximity to coastal states. In both the continental shelf and the EEZ the coastal state is recognized as having "sovereign rights" over living and non-living resources, for example, and limited jurisdiction rather than "sovereignty." The concept of sovereign rights implies limited control and authority for specific purposes, as opposed to total control for all purposes associated with sovereignty. In both the EEZ and the continental shelf, rights associated with the high seas, such as freedom of navigation and overflight, that are not contrary to the limited rights possessed by the coastal state continue to apply. This new, more sophisticated ocean legal regime clearly seeks to achieve an acceptable balance of rights, respecting coastal state and world navigational interests.

While there appears to be an accommodation of interests among coastal states and the broader world community, this by no means suggests that significant legal problems relating to jurisdiction do not exist; many important details have yet to be clarified by state practice. In the territorial sea, for example, there remain differences with respect to innocent passage of warships; a sizeable number of states maintain that foreign warships require coastal state notification or even authorization for passage through their territorial seas. Moreover, differences exist with respect to the precise balance contained in the package of rights and duties of coastal states in their new EEZs. Now that broad questions of jurisdiction have been addressed, legal attention will focus on the more precise nature of jurisdiction in particular zones.

The third, and perhaps the most significant trend in ocean law, is the growing understanding of the need for management of the physical environment of the oceans and its resources and uses. Recognition of the need for ocean management is manifested in a variety of provisions contained in the 1982 United Nations Law of the Sea Convention and stems from a basic alteration in the human perspective of the oceans. At an earlier time the oceans were viewed as virtually limitless in terms of the living resources they could generate year after year and in terms of the wastes they could safely assimilate and render harmless.

In fact, wider national claims to offshore areas by a variety of states have been fueled by the growing fear of fishery stock depletion due to the increasing activities of modern distant water fishing fleets. And even a cursory comparison of the 1958 United Nations Law of the Sea Conventions with the 1982 Convention quickly demonstrates the growing concern of the world community with marine pollution and environmental protection. More is known today of the physical ocean system and its ecology than in past decades. From the perspective of the 1982 Law of the Sea Convention, the oceans comprise a total environment, used by many for a host of different purposes with each use contributing to the cumulative impact on that environment. As noted in the Convention's preamble ". . . the problems of ocean space are closely interrelated and need to be considered as a whole..."

Just as a law of the sea regime requires balance among the interests of a number of states, so too does it 
require an attempt to reconcile alternative and competing uses and to recognize their synergistic implications for the well-being of ocean ecosystems. The disincentive to responsible behavior associated with the status of the oceans as a commons has been reversed to some extent through the establishment of national EEZs. Moreover, the new law of the sea creates strong incentives for effective management by the coastal state since it is that state that stands to benefit the most from such efforts.

The fourth major trend in ocean law is the recognition of the need for international coordination, cooperation, and institutional development in the governance of ocean space. The 1982 United Nations Law of the Sea Convention allocates control of ocean areas and their resources, placing the most heavily utilized portions of ocean space under the jurisdiction of coastal states. With basic jurisdictional questions addressed, attention now has turned to the matter of management, that is, the use and conservation of the resources and environment that come under national authority.

Such concern underscores the need for international cooperation at the regional and global levels (Alexander, 1994). The Convention clearly recognizes that in terms of management of the marine environment and its living, and non-living resources, national interests cannot be maximized absent cooperative international efforts. Whereas coastal nation-states appear to emerge triumphant with the expansion of their authority into areas once viewed as high seas, in many cases they still have at best limited control over events affecting the well-being of their expanded offshore zones and resources. Jurisdictional capacity within a wider zone such as the EEZ does not necessarily imply control sufficient to protect important interests in resources that migrate outside of that area or pollutants that may be transported into that area.

The expansion of national jurisdiction does not obviate the need for international cooperation; in many cases it accentuates its need by raising the stakes for those states involved. Regional cooperative efforts will be essential to turn formal authority and jurisdiction into meaningful or maximal benefits for each particular coastal state. Ironically, in this sense the jurisdictional triumph of coastal states will be accompanied by a new imperative for international cooperation. The adoption of the United Nations Fish Stocks Agreement that emphasizes the importance of regional fishery bodies indicates a heightened awareness of the need for international cooperation to manage stocks that move between EEZs and the high seas and also highly migratory species such as tuna (United Nations Fish Stocks Agreement, 1995).
Implications for ocean use management

Looking to the future, the aforementioned developments have contradictory implications for the short and long term. In the short term, states will continue the trend of seeking to maximize national authority in offshore areas to the extent made permissible by contemporary international law. Coastal and non-coastal states will test the limits to the sometimes vague and imprecise balances laid out by the new regime for the law of the sea, with each state trying to protect its perceived interests in the juridical zones of ocean space.

Without doubt, during the past half century, the balance between the rights of coastal states vis-á-zis those of other states within the territorial seas, the continental shelf, archipelagic waters, and the exclusive economic zone has moved toward the world's coastal states. However, the wider world community has very important interests in the rules applied to such zones of national authority, such as those associated with navigational rights, and must remain vigilant to ensure that tendencies toward "creeping jurisdiction" are checked (Knauss, 1985b).

In the longer term the need for interstate cooperation, already recognized and noted above, will increasingly manifest itself and will be seen specifically in terms of:

\section{- Greater involvement of international organiza- tions in marine affairs}

Developing states, especially, will call upon international organizations to provide assistance in several major ways to aid in the management and development of sometimes extremely large tracts of ocean space now under national jurisdiction. But developed states as well need and benefit from the coordinating capabilities of international organizations.

Organizations such as the Food and Agricultural Organization (FAO), the International Maritime Organization (IMO), and the United Nations Environmental Program (UNEP) will be looked to for their substantive expertise to provide technical assistance as attention increasingly turns to management questions. The Intergovernmental Oceanographic Commission (IOC) and the International Council for the Exploration of the Sea (ICES), as well as FAO, will be called upon for scientific expertise on matters ranging from coastal management to the impact of particular fishing gear on the marine environment to the application of the precautionary approach to fisheries (Freestone and Hey, 1996; Garcia, 1994). 
Other international bodies such as the United Nations Development Program (UNDP), the World Bank and the Global Environment Facility (GEF) will be looked to as sources of much needed funding to allow states to take full advantage of and execute the legal rights and responsibilities they have acquired through the evolution of ocean law. Further, institutions such as UNEP, FAO, and various regional fishery commissions will be expected to serve as catalysts or channels for required regional cooperation.

- An emphasis on regional cooperation in marine affairs

In the long term as states attempt to manage their new extended zones of offshore jurisdiction, it will become increasingly apparent that in many, if not most, areas such management cannot succeed without cooperative and coordinated efforts by states of a marine region (Alexander, 1994). National juris... ocean governance diction will, on many occasions, be too limited in spatial reach for effective management of marine resources and the marine environment; this is particularly true in the world's semi-enclosed seas as in the Mediterranean or the Baltic. In those areas the need for regional cooperation is already patently obvious as the task of management proceeds. The work of UNEP through its Regional Seas Program and the many regional agreements that have already emerged underscore this trend.

\section{- Growing interest in ecosystem-based management}

Now that state jurisdiction has been broadly determined, coastal states have strong positive incentives to manage offshore resources effectively. Increasing awareness of the high cost of environmental damage and pollution to coastal states will contribute further to management concerns. The burgeoning interest in protecting the marine environment and its resources will have to take into account expanding knowledge of ecosystem dynamics.

That such considerations have already entered into the international political realm is seen, for example, in the Antarctic Convention on Marine Living Resources (CCAMLR, 1980) that defines the treaty area utilizing the Antarctic convergence, a boundary based in ecosystem considerations. But the use of such a boundary remains exceptional; indeed, a basic problem that faces those concerned with ocean use management issues is the lack of congruence between "politically defined space," that is, the geographic area encompassed by particular human governance systems, and "ecologically and encourage cooperation on an international scale.

\section{Conclusion}

Whereas the contemporary law of the sea parcels out jurisdiction, authority, and responsibility among states, such compartmentalization will not prove successful in the absence of effective ocean management efforts. Such efforts must factor in the natural systems of the oceans Interdependence, in the sense that what happens in one place has implications elsewhere, will be more evident, as will the limited capability of states to achieve desirable outcomes individually. Accordingly, ocean governance may provide a major testing ground of human ability to

defined space," composed of the area over which Contemplation of large marine ecosystems as a possible basis for effective ocean management is but one example of ongoing concern with the need to
address this matter (Alexander, 1993; Sherman, 1995).

international basis for the management

\section{REFERENCES}

Alexander, L.M., 1983: The Ocean Enclosure Movement: Inventory and Prospect. San Diego Law Reriezw, 20, 561-594.

Alexander, L.M., 1986: Navigational Restrictions Within the New LOS Context: Geographical Implications for the United States. Peace Dale, Offshore Consultants, Inc.

Alexander, L.M., 1993: Large Marine Ecosystems: A New Focus for Marine Resources Management. Marine Policy, 17, 186-198.

Alexander, L.M., 1994: New Trends in Marine Regionalism. In: Ocean Yearbook 11. E.M. Borgese, et al., eds., University of Chicago Press, Chicago, 1-8.

Attard, D., 1987: The Exclusive Economic Zone in International Law. Oxford, Clarendon Press.

Ball, W.S., 1996: The Old Grey Mare: National Enclosure of the Oceans. Ocean Development \& International Law, 27, 97-124. Antarctic Marine Living Resources. International Legal Materials, 19, 837-859.

Eckert, R., 1979: The Enclosure of Ocean Resources. Hoover Institution Press, Stanford.

Freestone, D. and E. Hey (eds.), 1996: The Precautionary Principle and International Law: the Challenge of Implementation. Kluwer Law International, The Hague.

Garcia, S.M., 1994: The Precautionary Principle: Its Implications in Capture Fisheries Management. Ocean \& Coastal Manugement, 22, 99-125.

Juda, L, 1996: International Laze and Ocean Use Management: The Evolution of Ocean Governance. cooperate on an international basis for the
of natural resources and the environment.

CCAMLR, 1980: Convention for the Conservation of 
Routledge, London.

Juda, L., 1999: Considerations in Developing a Functional Approach to the Governance of Large Marine Ecosystems. Ocean Development $\mathcal{E}$ International Law, 30, 89-125.

Knauss, J., 1985a: The Effects of the Law of the Sea on Future Marine Scientific Research and of Marine Scientific Research on the Future Law of the Sea. Louisiana Law Review, 45, 1201-1219.

Knauss, J., 1985b: Creeping Jurisdiction and Customary International Law. Ocean Development \& International Law, 15, 209-216.

Orrego Vicuña, F. (ed.), 1984: The Exclusive Economic Zone: A Latin American Perspective. Westview Press, Boulder.
Prescott, J.R.V., 1985: The Maritime Political Boundaries of the World. Methuen, London.

Roach, J.A. 1996: Marine Scientific Research and the New Law of the Sea. Ocean Development $\mathcal{E}$ International Law, 27, 59-72.

Sherman, K., 1995: Achieving Regional Cooperation in the Management of Marine Ecosystems: The Use of the Large Marine Ecosystem Approach. Ocean $\mathcal{E}$ Coastal Management, 29, 165-185.

United Nations Convention on the Law of the Sea, 1982: International Legal Materials, 21, 1261-1354.

United Nations Fish Stocks Agreement, 1995: International Legal Materials, 34, 1547-1580. ohn Knauss has a lot of facets. From 1968-1987, while I was at La Spezia and Woods Hole, he was just an "important name" I had seen on ocean circulation papers, in charge of conferences, as the University of Rhode Island (URI) Dean, etc. He attended a few of the Friday night biweekly Geophysical Fluid Dynamics Seminars that rotated between Woods Hole Oceanographic Institution, Massachusetts Institute of Technology, and Harvard, with occasional forays to Yale, Brown, and URI. He did not engage in the usual mathematical questions-and-answers, but saved his bullets for probing questions like "Why do you think that?" and "How did you come to that conclusion?" and "So what?" These are paraphrases, not quotes: I do not remember the details of his comments, but remember being impressed that he was not apparently enamored of or swayed by all the integral signs; I sensed a kindred spirit.

Then I joined the Office of Naval Research (ONR). One of my very first jobs - at a URI Site Review - was to tell John we weren't going to give him all the money he had asked for, which involved some remote sensing data of the Brazil Current. The "important name" turned out to be a gentleman as well, and helped me get through the meeting gracefully as we negotiated.

I moved to the National Oceanic and Atmospheric Administration (NOAA) in 1991, while John was its Administrator. He turned the tables almost immediately and showed he held no grudge: he gave me some start-up money to try and kick off some of the early activities in the Global Ocean Observing System (GOOS). The important name and gentleman became a benefactor. His words of guidance on GOOS were quite simple; in effect he said this is worth doing, and it is time to do it, so get together with people who want to make it happen and work with them. John then left NOAA, and so did I a few years later. He returned to a split life in Rhode Island and La Jolla, and I returned to ONR.

We keep crossing paths via the Ocean Studies Board and various governmental committees like the Ocean Research Advisory Panel of the National Oceanographic Partnership Program. He always strikes me as someone who is wise and is ready with his counsel, but never quite believing of the ponderous nature of getting things done in Washington. The senior citizen-oceanographer delivers a boyish enthusiasm about new ideas, and never seems to lose his optimism for things like GOOS. I'm sure he thinks it is still a good idea, and it is still time to do it.

Another NOAA person when I was there with John was the late Ned Ostenso. One of Ned's sayings was that "you can lead with a carrot or you can lead with a stick, but you can't lead with a tin cup." John Knauss proves another alternative is viable: he leads with a quiet but forceful intellectual strength, an avoidance of fluff, and a focus on defensible objectives.

The Washington Post recently reported on a document making the rounds of Washington, called "Rumsfeld's Rules." One of them is quite elegant: "Remember: A's hire A's and B's hire C's." The quality of people at URI attests to John's tenure there and to his being an A.

These are a lot of facets, plus he has won the muchcoveted Albatross Award from the American Miscellaneous Society. We are all fortunate to know him.

Melbourne G. Briscoe Office of Naval Research Arlington, VA USA 